The Israeli Journal of Aquaculture - Bamidgeh •ISSN 0792-156X •IJA.73.2021.1546029, 15 pages

CCBY-NC-ND-4.0 • https://doi.org/10.46989/001c.31303

The IJA is a peer-reviewed open-access, electronic journal, freely available without charge to users

Produced by the AquacultureHub non-profit Foundation Sale of IJA papers is strictly forbidden

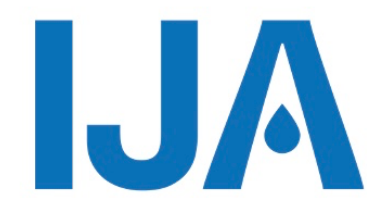

\title{
A comparison of the physiological responses to heat stress of juvenile and adult starry flounder (Platichthys stellatus)
}

\section{Hyo Bin Lee ${ }^{1}$, Ji Hye Yoon ${ }^{1}$, Jung Yeol Park², Il Young Lee ${ }^{3}$, Han Kyu Lim¹,2*}

${ }^{1}$ Department of Biomedicine, Health \& Life Convergence Sciences, BK 21, Mokpo National University, Muan, Jellanam-do 58554, Republic of Korea

2 Department of Marine and Fisheries Resources, Mokpo National University, Muan, Jellanam-do 58554, Republic of Korea

${ }^{3}$ Marine Seed Hatchery, Yeosu, Jellanam-do 59777, Republic of Korea

Key words: Platichthys stellatus, Heat response, Cortisol, HSP70

\begin{abstract}
Water temperature is the most important factor in fish farming as changes in water temperature cause physiological stress in fish. There have been few studies on physiological responses to high temperatures, which vary with aging. This study investigated the responses of juvenile and adult Platichthys stellatus to heat stress. Plasma cortisol, glucose, lactate, and lysozyme levels, antioxidant enzyme activities, and expression of heat shock proteins 70 and 90 (HSP70 and HSP90) of $P$. stellatus were determined at water temperatures of $16,20,24,28$, and $30^{\circ} \mathrm{C}$. As a result, it was confirmed that several plasma parameters of adult were significantly higher than that of juvenile under heat stress. Plasma cortisol and glucose levels of adult were increased than juvenile at 24 and $28^{\circ} \mathrm{C}$. Plasma lactate level of adult were higher than that of juvenile at $28^{\circ} \mathrm{C}$. Comparisons of survival and physiological changes showed that juveniles have better thermal tolerance, resulting in a higher cumulative survival rate. Moreover, the relationship between thermal tolerance and HSP gene expression revealed that expression of HSP70 and HSP90 was significantly upregulated at $28^{\circ} \mathrm{C}$ in both juvenile and adult fish, and HSP70 expression was significantly higher in juvenile fish than in adult fish. It is judged that the adult's HSP70 activity was lower than juvenile, so the demand for plasma parameters for heat response was relatively high, whereas juvenile's HSP70 activity increased at 24 and $28^{\circ} \mathrm{C}$, indicating a relatively stable value of plasma parameters. These results indicate that the thermal tolerance of juvenile fish is greater than that of adult fish, based on the differences in plasma parameters and HSP expression. These findings improve our understanding of age-related changes in $P$. stellatus during thermal stress and may help guide the management of fish farms.
\end{abstract}




\section{Introduction}

Water temperature influences ectotherm physiology (Paaijmans et al., 2013; Hamdan et al., 2015; Payne et al., 2016). Recent increases in water temperature due to climate change have had a profound effect on aquatic ectotherms, including teleosts (Lee et al., 2014; Alfonso et al., 2021). Fish adapt to changes in water temperature by controlling the rate of metabolic activities, although the fish must maintain their biological activity within tolerable thermal limits (Radoslav et al., 2013; Kim et al., 2019). Temperatures above tolerance thresholds can lead to changes in growth rate, enzymatic activities, and metabolic rate, leading to homeostatic overload or failure. Thermal stress exerts adverse effects on immune function and the cellular response of fish; these can be measured using known indicators (Liu et al., 2010; Lu et al., 2016). Thermal stress initially stimulates the hypothalamic-pituitary-internal axis, secretes cortisol into the blood, and initiates primary responses to stress (Wu et al., 2017). Cortisol is the predominant circulating corticosteroid in fish, and stress results in elevated plasma cortisol levels (Barton and Iwama, 1991; Pottinger et al., 1994). As cortisol increases the metabolic rate of fish, it may be involved in an adaptive mechanism to prevent excess energy mobilization during recovery from stress, thereby assisting in regaining metabolic homeostasis (Sathiyaa et al., 2001). Several studies have described plasma cortisol profiles in response to various stressors and the physiologic consequences of elevated cortisol levels in fish (Fevolden et al., 1991; Pottinger and Carrick, 1999; Ruane et al., 2001; Fast et al., 2008; Di Marco et al., 2008; Ramsay et al., 2009). Plasma glucose levels in fish also increase following exposure to stressful stimuli (Pottinger and Carrick, 1999; Barton, 2000; Begg and Pankhurst, 2004; Lowe and Davison, 2005; Mirghaed et al., 2017; Jiang et al., 2017). Induction of glucose production increases the energy demand under high water temperature by regulating carbohydrate metabolic pathways (Hemre et al., 2002; Guillen et al., 2019). Increased levels of lactate in plasma have been observed in flatfish exposed to different stressors such as air exposure, handling, high density, and thermal shock (López-Patiño et al., 2013; Gesto et al., 2016). Lactate is significantly increased under stress conditions and can be used as a stress response marker in Senegalese sole, Solea senegalensis (Conde-Sieira et al., 2018). Some of the effects of thermal stress on innate immunity in fish include alterations in lysozyme activity (Fletcher and White, 1976; Muona and Soivio, 1992; Ndong et al., 2007; Cheng et al., 2009). For example, in an experiment with rainbow trout, Oncorhynchus mykiss (Möck and Peters, 1990), chronic 2-h transport stress reduced lysozyme activity significantly. Thermal stress can lead to oxidative stress via the production of reactive oxygen species (ROS) and in organisms unable to detoxify the ROS or repair injury (Paital and Chainy, 2016; Paital et al., 2016). ROS damage cells, and to cope with these injuries, cells express antioxidant enzymes such as superoxide dismutase (SOD) and catalase (CAT) (Yu et al., 2017).

High levels of heat-shock proteins (HSPs) are induced in response to environmental changes such as heat stress to protect both prokaryotic and eukaryotic cells from environmental stresses by acting as a molecular chaperone (Feder and Hofmann, 1999; Voellmy and Boellmann, 2007; Jacob et al., 2017). HSP70 is involved in chronic temperature acclimation and the acute response of organisms to temperature challenge (Pérez-Casanova et al., 2008; Yamashita et al., 2010). HSP90 supports various components of the cytoskeleton and is involved in a variety of cellular processes, including control of apoptosis in the stress response (Csermely et al., 1998; Fu et al., 2011; Wei et al., 2013; Xu et al., 2014). Heat stress upregulates HSP70 and HSP90 expression in teleosts (Iwama et al., 1998; Basu et al., 2002; Kayhan and Duman, 2010; Kelly et al., 2018); therefore, both HSP70 and HSP90 can be useful biomarkers for assessing heat stress in fish (Tedeschi et al., 2015). Many of the functional roles of HSPs are known, but the underlying mechanisms are still unclear. HSPs may also be useful as markers of cellular injury and for diagnostic and therapeutic purposes (Kregel, 2002).

The starry flounder, Platichthys stellatus, is an important commercial flatfish in Korea, North China, and Japan. Olive flounder, Paralichthys olivaceus, Korea's main aquaculture fish species, has been suffering from a decline in price competitiveness due to mass 
production, and $P$. stellatus is emerging as a high-value-added aquaculture target species to replace $P$. olivaceus. The optimum temperature for growth of $P$. stellatus ranges from $15^{\circ} \mathrm{C}$ to $19^{\circ} \mathrm{C}$ (Oh et al., 2009; Kim, 2012); feeding and growth are maintained at under $18^{\circ} \mathrm{C}$ (Byun et al., 2008). Above $24^{\circ} \mathrm{C}$, the fish are stressed, with osmoregulatory disturbances (Min et al., 2015). Since 2016, hot summers have repeatedly affected $P$. stellatus aquaculture farms close to the shore on the east coast of Korea, with temperatures climbing to $28^{\circ} \mathrm{C}$ or higher, inducing long-term stress responses, lowered immunity and mass mortality. As a result, the farms have suffered heavy financial losses. However, during recent high summer temperatures, only adult fish died; juvenile fish survived. Thus, it was hypothesized that there is an age-related difference in the heat resistance of $P$. stellatus at relatively high temperatures. The thermal tolerance of fish may depend on intrinsic factors such as age (Fowler et al., 2009; Turko et al., 2020). Several studies have revealed that juvenile and subadult fishes are often more tolerant of warm conditions compared with larvae (Drost et al., 2016; Moyano et al., 2017) and mature adults (Troia et al., 2015). These studies highlighted the need to evaluate the thermal tolerance of fish species at different stages, and that it is important to understand how heat resistance varies with age to predict the effects of thermal stress in fish populations.

In this study, differences in the physiological responses to heat stress of juvenile and adult $P$. stellatus were investigated. We compared their survival rates and physiological changes using plasma analysis and analyzed the relationship between thermal tolerance and HSP gene-expression patterns.

\section{Materials and Methods}

\section{Ethical statement}

All procedures were performed in accordance with the guidelines for the ethical treatment of animals and were approved by the institutional animal care and use committee of Mokpo National University (No. 1183; December 17, 2013).

\section{Experimental fish}

The experiments were conducted at the Marine Seed fish farm located in Yeosu, Korea. Two experimental groups were examined: $90 \mathrm{P}$. stellatus juveniles with a total length of $122.1 \pm 6.47 \mathrm{~mm}$ and weight of $28.08 \pm 4.8 \mathrm{~g}$, and $90 P$. stellatus adult fish with a total length of $313.0 \pm 21.64 \mathrm{~mm}$ and weight of $524.45 \pm 64.03 \mathrm{~g}$. The experimental fish were first acclimated to a water temperature of $16^{\circ} \mathrm{C}$ and salinity of 33 psu for 7 days and were fed twice a day.

\section{Heat stress and sample collection}

The fish were housed in three tanks containing 30 juvenile and three tanks containing 30 adult $P$. stellatus. First, the temperature of each tank was elevated at a rate of $1^{\circ} \mathrm{C}$ per $12 \mathrm{~h}$ until reaching the target temperature, $34^{\circ} \mathrm{C}$. This temperature was then maintained using thermostatic heaters. Dissolved oxygen was maintained at above 7.0 $\mathrm{mg} / \mathrm{L}$ by supplying liquefied oxygen during the experiment. The control temperature was $16^{\circ} \mathrm{C}$. Figure 1 shows details of the increase in temperature. Fish survival was checked every $12 \mathrm{~h}$; juvenile and adult fish without opercular movement and with no response to mechanical stimuli were considered dead and were removed from the tanks. Lethal temperature (LT50), defined as the temperature at which $50 \%$ of a population dies, was measured based on the method of Stirling (1982) with some modifications (Kilgour and McCauley, 1986). Blood and tissue sampling were conducted at $20,24,28$, and $30^{\circ} \mathrm{C}$. Fish were anesthetized with $100 \mathrm{mg} / \mathrm{L}$ tricaine methane sulfonate (MS-222, Sigma, Burlington, MA, USA) before blood samples and tissues were collected. Blood samples were obtained from the caudal vein of six juvenile and six adult fish from each tank using $18 \mathrm{G}$ and $23 \mathrm{G}$ syringes, respectively. Blood samples were centrifuged at $1000 \times \mathrm{g}$ for 10 min. Plasma was collected and stored at $-80^{\circ} \mathrm{C}$ until analysis. After blood collection, the 
fish were dissected and kidney tissue was sampled. The specimens were then frozen in liquid nitrogen until RNA extraction.

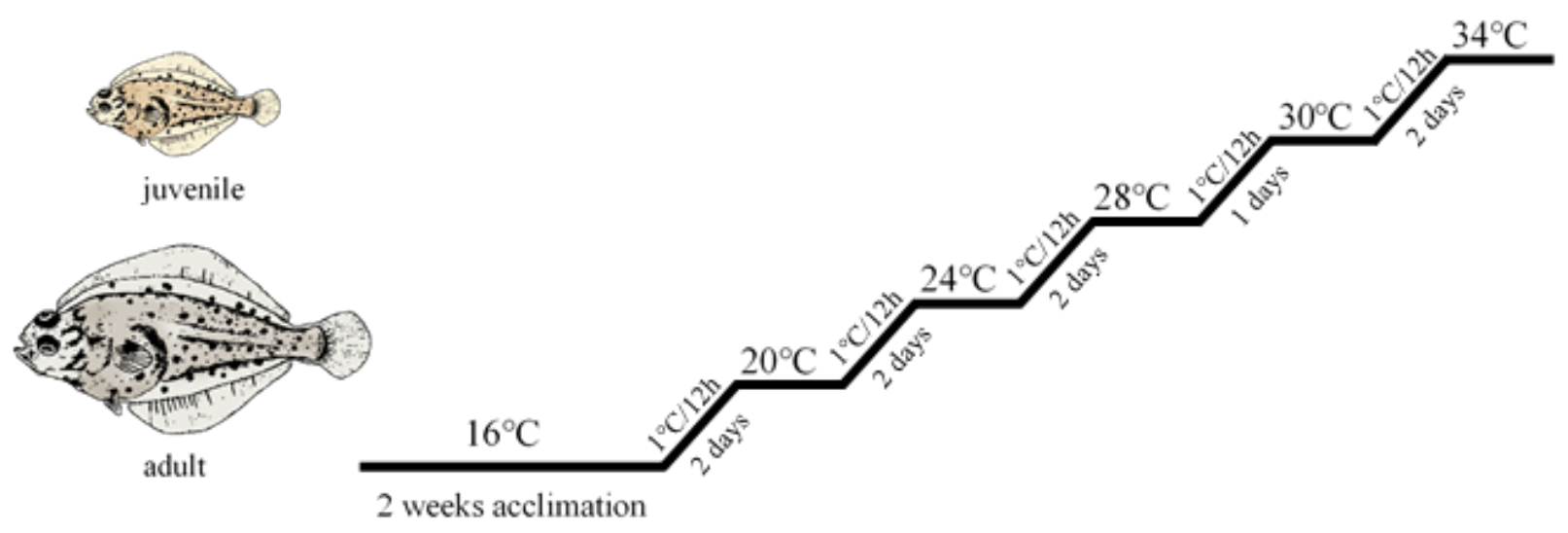

Figure $1 \mathrm{Scheme}$ of the increasing water temperature protocol from $16^{\circ} \mathrm{C}$ to $30^{\circ} \mathrm{C}$ in juvenile and adult Platichthys stellatus.

\section{Plasma analysis}

Plasma levels of cortisol were measured using a Fish Cortisol ELISA kit (MyBiosource, San Diego, CA, USA), and all plasma samples were analyzed in duplicate. For the assay, $50 \mu$ of fish plasma sample and $50 \mu$ l of standard solution were added to per well. $50 \mu$ of antibody-HRP-conjugate solution was added to each well except blank, and mixed well, incubated for 1 hours at $37^{\circ} \mathrm{C}$. Then, the solution of each well removed and washed three times with $250 \mu \mathrm{l}$ of $1 \mathrm{X}$ wash buffer. $50 \mu \mathrm{l}$ of substrate $A$ and $50 \mu$ l of substrate B solution were added to each well, and incubated for $15 \mathrm{~min}$ at $37^{\circ} \mathrm{C}$. After added $50 \mu \mathrm{l}$ of stop solution, determined the optical density (OD) of each well within $5 \mathrm{~min}$, using a SpectraMax 190 microplate reader (Molecular Devices, San Jose, CA, USA) set to 450nm. Standard curve constructed and the concentration of samples can be determined by regression analysis.

Plasma levels of glucose were measured using a Glucose Assay Kit (MyBioSource). $50 \mu$ of each glucose standard and plasma samples were added into wells, and $50 \mu$ of reaction mix solution was added to each well. Then, incubated for $40 \mathrm{~min}$ at $37^{\circ} \mathrm{C}$ protected from light. After incubation, using a microplate reader in the 540-570nm range. The concentration of glucose within samples calculated by comparing the sample OD to the standard curve.

Plasma lactate levels were measured using an L-Lactate Assay Kit (Abcam, Cambridge, UK). $50 \mu \mathrm{l}$ of standard and plasma samples were added to per well, and $50 \mu \mathrm{l}$ of reaction mix including assay buffer, substrate mix, and enzyme mix was added to wells. Then, $50 \mu l$ of background reaction mix to control wells, and incubated at room temperature for $30 \mathrm{~min}$. The plate measured at OD $450 \mathrm{~nm}$ in a microplate reader. Average of each standard and samples were subtracted the sample background control, and absorbance values were plotted for as a function of the final concentrations of lactate.

Plasma lysozyme activity was measured using a Fish Lysozyme ELISA kit

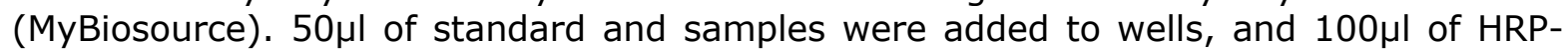
conjugate reagent was added to every well except blank wells. The plate was covered and incubated for $60 \mathrm{~min}$ at $37^{\circ} \mathrm{C}$, and all wells were washed 4 times. $50 \mu$ l of chromogen solution $A$ and $50 \mu$ l of chromogen solution B were added to every well, and incubated for $15 \mathrm{~min}$ at $37^{\circ} \mathrm{C}$. Then, $50 \mu \mathrm{l}$ of stop solution was added to all wells, the OD of the plate was read at $450 \mathrm{~nm}$ using a microplate reader within $15 \mathrm{~min}$. Average of all standard and samples were subtracted average OD of the blank, and standard curve was made and calculate the level of the analyses.

Antioxidant enzyme activities were analyzed using a Fish Superoxide Dismutase ELISA kit (MyBiosource) and a Fish Catalase ELISA kit (MyBiosource). According to protocol of 
SOD assay kit, $50 \mu \mathrm{l}$ of standard and samples were added to per well. And $50 \mu \mathrm{l}$ of antibody-HRP-conjugate solution was added to each well, incubated for 60 min at $37^{\circ} \mathrm{C}$. Each well was aspirated and washed using $250 \mu \mathrm{l}$ of wash buffer three times. $50 \mu \mathrm{l}$ of substrate $A$ and $B$ were added to all wells, and incubated for $15 \mathrm{~min}$ at $37^{\circ} \mathrm{C}$. After added $50 \mu$ l of stop solution, the OD of each well was determined using a microplate reader set to $450 \mathrm{~nm}$. The levels of SOD within samples calculated by comparing the sample OD to the standard curve. Plasma levels of CAT were performed in the same way as the SOD assay kit protocol.

\section{HSP gene-expression analysis}

Total RNA extraction and CDNA synthesis

Total RNA was extracted from kidney using the TRIzol ${ }^{\circledR}$ protocol (Invitrogen, Waltham, MA, USA). DNase I (Qiagen, Hilden, Germany) was added to prevent DNA contamination. RNA degradation and contamination were assessed on a $1 \%$ agarose gel. cDNA was synthesized from purified total RNA using a Maxima First Strand cDNA Synthesis Kit (Thermo Fisher Scientific, Waltham, MA, USA). The synthesized CDNA was quantified using Nanodrop One C (Thermo) and stored at $-80^{\circ} \mathrm{C}$.

Quantitative real-time $P C R$

The primers used for quantitative real-time PCR (qRT-PCR) are listed in Table 1. qRTPCR was performed using a Pikoreal 96 RealTime PCR System (Thermo Fisher Scientific) to examine the expression of HSP70 and HSP90 with increasing water temperature. The concentration of cDNA was adjusted to $100 \mathrm{ng} / \mu \mathrm{L}$. The triplicate $20-\mu \mathrm{L}$ reaction volumes contained $11 \mu \mathrm{L}$ SYBR Green PCR Master Mix (Promega, WI, USA), $1 \mu \mathrm{L}$ each primer $(10 \mathrm{pM}), 1 \mu \mathrm{L} C D N A$, and $7 \mu \mathrm{L}$ sterile water. The qRT-PCR cycling conditions were preincubation at $50^{\circ} \mathrm{C}$ for $2 \mathrm{~min}$, pre-denaturation at $95^{\circ} \mathrm{C}$ for $7 \mathrm{~min}$, followed by 40 cycles of denaturation at $95^{\circ} \mathrm{C}$ for $15 \mathrm{sec}$, annealing at $55^{\circ} \mathrm{C}$ for $30 \mathrm{sec}$, and extension at $72^{\circ} \mathrm{C}$ for $20 \mathrm{sec}$. Melting curves were also plotted $\left(60-90^{\circ} \mathrm{C}\right)$ to ensure that a single PCR product was obtained for each pair of primers. The expression levels of HSP70 and HSP90 in kidney were calculated relative to those of the housekeeping gene glyceraldehyde3phosphate dehydrogenase (GAPDH) using the $2^{-\Delta \Delta \mathrm{Ct}}$ method with mean Ct values.

Table 1 Primer sequences used in this study.

\begin{tabular}{lll}
\hline Primers & Primer sequence 5' $\mathbf{- 3}$ & Primer efficiency \\
\hline Hsp70_FW & CGATTGTCTACGGCTTGGAT & $97.50 \%$ \\
Hsp70_RV & TCTTCGCTCTCTCACAAGCA & $97.50 \%$ \\
Hsp90_FW & GACCAAGGCCGATCTGATAA & $95.04 \%$ \\
Hsp90_RV & CTGCTCGTCATCATTGTGCT & $95.04 \%$ \\
GAPDH_FW & CCAGAACATCATCCCAGCTT & $98.78 \%$ \\
GAPDH_RV & GGCCTTCACAACCTTCTTGA & $98.78 \%$ \\
\hline
\end{tabular}

\section{Statistical analyses}

For each analysis, the mean and standard error were calculated, and one-way ANOVA, Duncan's multiple range test, and Student's $t$-test were performed using the SPSS statistics program (version 24) to test for significant differences between measurements $(P<0.05)$. 


\section{Results}

\section{LT50 test}

Until the water temperature reached $24^{\circ} \mathrm{C}$, there were no significant differences between juvenile and adult $P$. stellatus, but from $28^{\circ} \mathrm{C}$ to $34^{\circ} \mathrm{C}$, the mortality rate of adult was significantly higher than that of juvenile fish. The results for upper $\mathrm{LT}_{50}$ are shown in Figure 2. The upper $\mathrm{LT}_{50}$ values for adult and juvenile $P$. stellatus were $28.5^{\circ} \mathrm{C}$ and $33.5^{\circ} \mathrm{C}$.

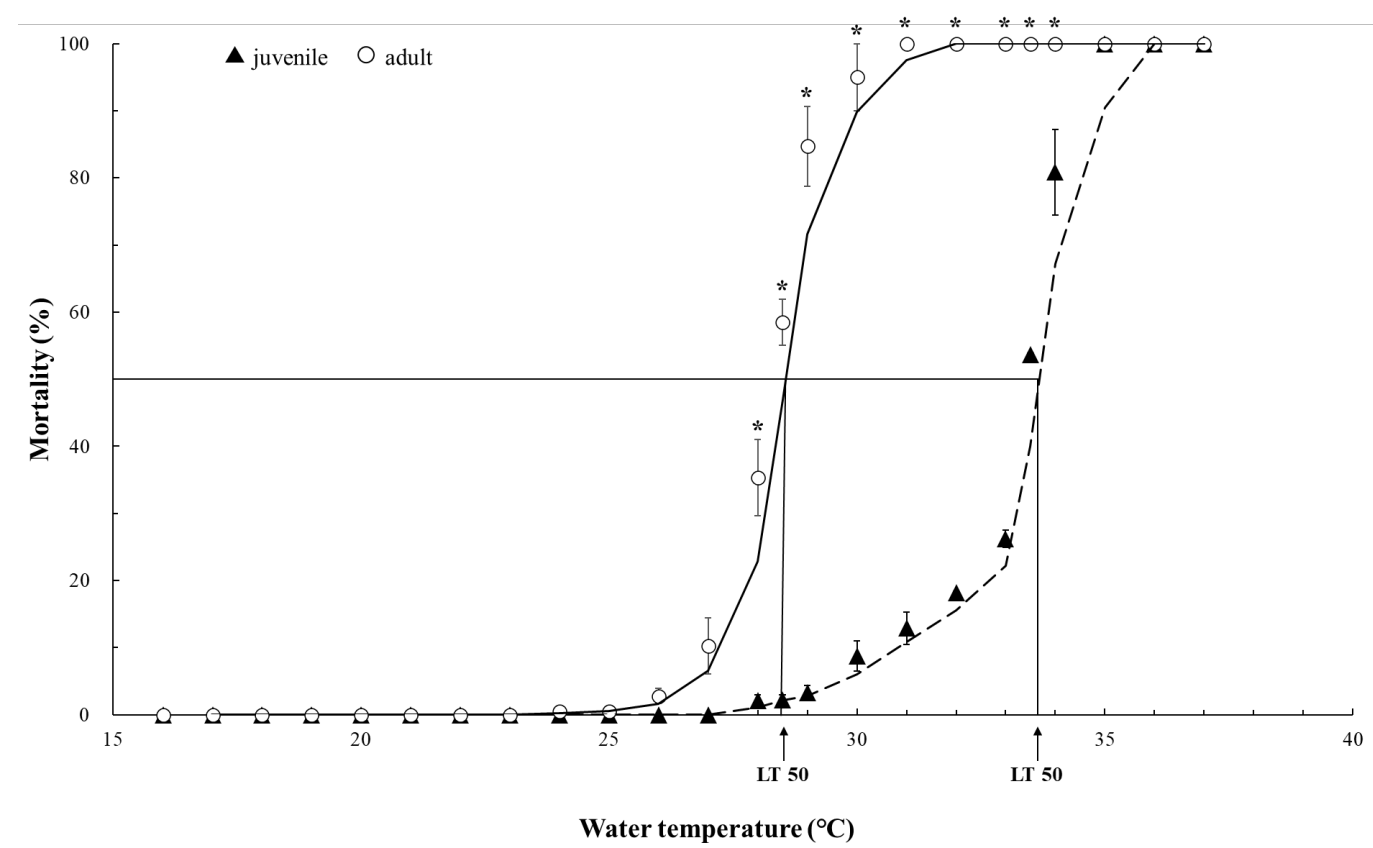

Figure 2 Determination of the $50 \%$ lethal temperature $\left(\mathrm{LT}_{50}\right)$ of juvenile and adult Platichthys stellatus. The arrow indicates the $\mathrm{LT}_{50}$. Each mark corresponds to the mean $\pm \mathrm{SE}$ of three determinations. Asterisks indicate significant differences between juveniles and adults at that sampling time $(P<0.05)$.

\section{Plasma levels}

The biochemical activities following exposure to increasing water temperatures are presented in Figure 3. During the experiment, the plasma cortisol levels of adult $P$. stellatus increased significantly at water temperatures of $24^{\circ} \mathrm{C}$ and $28^{\circ} \mathrm{C}(7.09 \pm 0.88$ $\mathrm{ng} / \mathrm{mL}$ and $8.55 \pm 0.19 \mathrm{ng} / \mathrm{mL}$, respectively). Those of juvenile fish increased significantly at $28^{\circ} \mathrm{C}(4.98 \pm 0.69 \mathrm{ng} / \mathrm{mL})$. In addition, levels in adult fish were significantly higher than in juveniles at $24^{\circ} \mathrm{C}$ and $28^{\circ} \mathrm{C}(P<0.05)$.

Plasma glucose levels differed significantly between juvenile and adult fish at water temperatures $\geq 24^{\circ} \mathrm{C}$, similar to cortisol levels $(P<0.05)$. At $24^{\circ} \mathrm{C}$, the glucose level in juvenile fish was $131.77 \pm 5.48 \mu \mathrm{g} / \mathrm{mL}$, compared with $298.85 \pm 60.15 \mu \mathrm{g} / \mathrm{mL}$ in adult fish. At $28^{\circ} \mathrm{C}$, the glucose level was significantly higher in adult fish than in juvenile fish $(361.93 \pm 98.62$ vs. $149.5 \pm 14.36 \mu \mathrm{g} / \mathrm{mL})$. At $30^{\circ} \mathrm{C}$, the glucose level in adult fish decreased, and there was no longer a significant difference from that in juveniles (130.49 \pm 3.69 vs. $115.16 \pm 14.87 \mu \mathrm{g} / \mathrm{mL}$ ).

Plasma lactate levels also differed significantly between juvenile and adult fish at water temperatures $\geq 24^{\circ} \mathrm{C}(\mathrm{P}<0.05)$. At $24^{\circ} \mathrm{C}$, the lactate level was $1.08 \pm 0.16 \mathrm{nmol} / \mathrm{L}$ in juvenile fish and $8.03 \pm 0.83 \mathrm{nmol} / \mathrm{L}$ in adult fish. The lactate levels of juvenile and adult fish increased rapidly to $7.81 \pm 1.1$ and $23.22 \pm 0.61 \mathrm{nmol} / \mathrm{L}$ at $28^{\circ} \mathrm{C}$ and decreased to $6.15 \pm 0.62$ and $18.76 \pm 1.72 \mathrm{nmol} / \mathrm{L}$ at $30^{\circ} \mathrm{C}$, respectively.

Plasma lysozyme levels were significantly higher in adults than in juveniles at 20 and $28^{\circ} \mathrm{C}$, but significantly higher in juveniles than in adults at $30^{\circ} \mathrm{C}(\mathrm{P}<0.05)$. The lysozyme 
concentrations in juvenile and adult fish were $128.22 \pm 4.06$ and $168.01 \pm 5.74 \mu \mathrm{g} / \mathrm{mL}$ at $20^{\circ} \mathrm{C}, 129.81 \pm 7.66$ and $179.06 \pm 10.41 \mu \mathrm{g} / \mathrm{mL}$ at $28^{\circ} \mathrm{C}$, and $129.13 \pm 4.64$ and $100.39 \pm 9.45 \mu \mathrm{g} / \mathrm{mL}$ at $30^{\circ} \mathrm{C}$, respectively.

Plasma SOD levels were significantly higher in adult fish than in juvenile fish at all temperatures except $20^{\circ} \mathrm{C}(\mathrm{P}<0.05)$. The SOD level in juvenile fish was highest at 35.81 $\pm 1.38 \mathrm{IU} / \mathrm{mL}$ at $20^{\circ} \mathrm{C}$ and decreased to $2.05 \pm 0.7 \mathrm{IU} / \mathrm{mL}$ as the water temperature increased to $30^{\circ} \mathrm{C}$. The SOD level in adult fish was highest at $61.02 \pm 0.95 \mathrm{IU} / \mathrm{mL}$ at $24^{\circ} \mathrm{C}$ and decreased significantly to $29.56 \pm 6.37 \mathrm{IU} / \mathrm{mL}$ at $30^{\circ} \mathrm{C}$.

Plasma CAT concentrations differed significantly between juvenile and adult fish at $16^{\circ} \mathrm{C}(5.1 \pm 1.26$ vs. $15.0 \pm 1.62 \mathrm{U} / \mathrm{mL}, \mathrm{P}<0.05)$. The CAT concentrations in juvenile and adult fish were highest at $28^{\circ} \mathrm{C}(15.59 \pm 1.29$ and $18.18 \pm 1.14 \mathrm{U} / \mathrm{mL}$, respectively $)$.
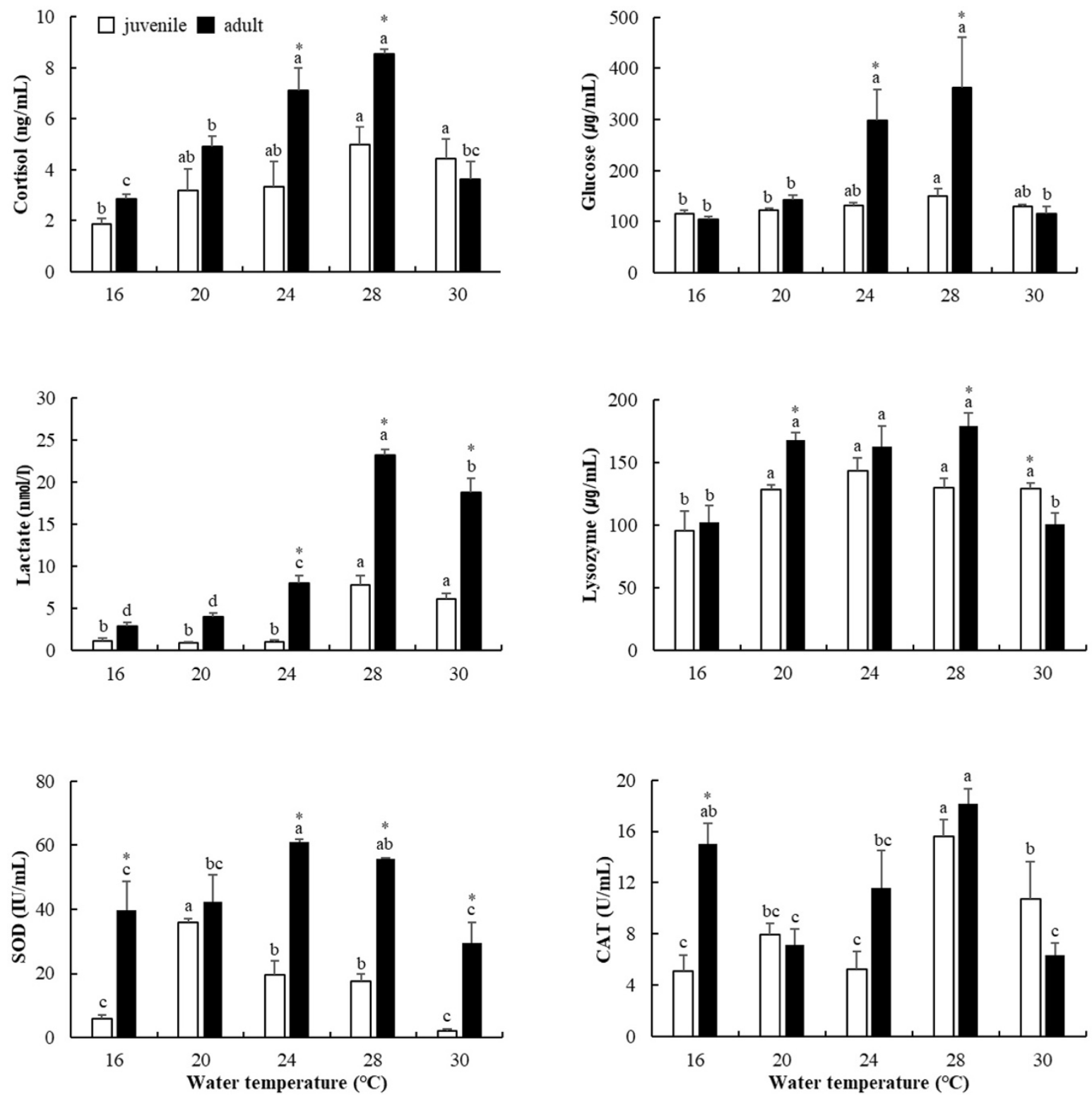

Figure 3 Levels of plasma parameters of Platichthys stellatus with increasing water temperatures. Data are presented as means \pm SEM. Bars with different letters indicate significant differences among the water-temperature groups $(P<0.05, n=6)$. Asterisks indicate significant differences between juveniles and adults at that sampling time $(P<0.05)$. 


\section{HSP gene expression}

The relative gene expression levels of HSP70 and HSP90 according to water temperature are shown in Figure 4. Expression of HSP70 in kidney was significantly higher in juvenile $P$. stellatus than in adults at 24,28 , and $30^{\circ} \mathrm{C}(P<0.05)$. Expression of HSP70 at $28^{\circ} \mathrm{C}$, when expression was highest, was 43.5 -fold and 74.9 -fold higher in adults than in juveniles, respectively. At $30^{\circ} \mathrm{C}$, expression of HSP70 was 33.8- and 21.8fold lower in juvenile and adult fish than that at $16^{\circ} \mathrm{C}$, respectively.

Expression of HSP90 did not differ significantly between juvenile and adult fish $(P<0.05)$ at any tested temperature. The levels in both juvenile and adult fish increased sharply at $28^{\circ} \mathrm{C}$, by 53.1 - and 50.7 -fold, respectively, relative to levels at $16^{\circ} \mathrm{C}$. Expression levels of HSP90 were $8.2-$ and 13.6 -fold lower in juvenile and adult fish at $30^{\circ} \mathrm{C}$ than at $16^{\circ} \mathrm{C}$, respectively.

A

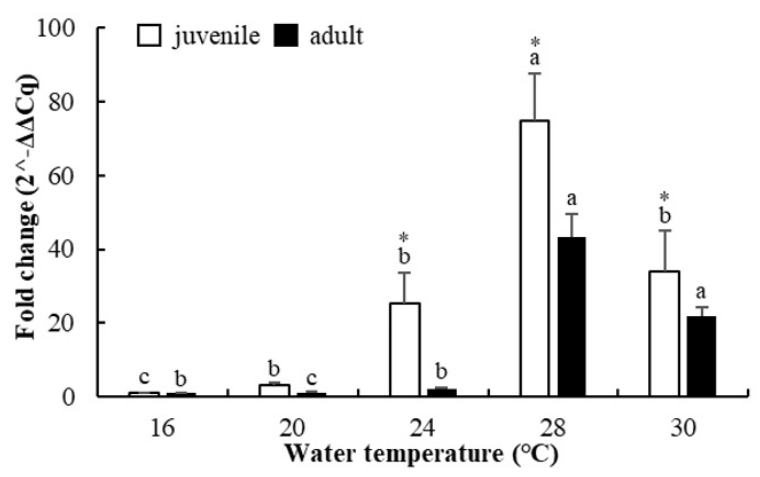

B

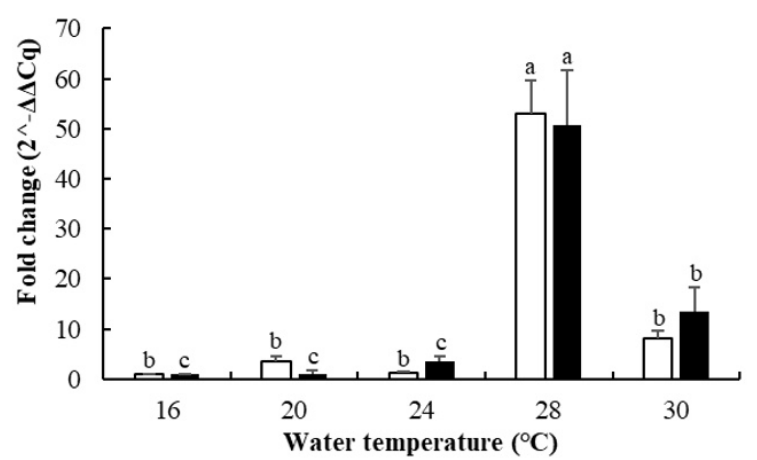

Figure 4 Relative mRNA expression of HSP70 (A) and HSP90 (B) of Platichthys stellatus during thermal stress. Data are presented as means \pm SEM. Bars with different letters indicate significant differences among the water-temperature groups $(P<0.05, n=6)$. Asterisks indicate significant differences between juveniles and adults at that sampling time $(P<0.05)$.

\section{Discussion}

P. stellatus is an economically important flounder species in East Asia (Min et al., 2015). However, mass mortality frequently occurs during hot summer months, resulting in very heavy losses and hindering the development of the $P$. stellatus aquaculture industry. During periods of high temperature in recent summers, juvenile fish in Korean fish farms survived, whereas large numbers of adult fish died. In this study, a comparative analysis of the physiological responses of juvenile and adult fish underlying thermal tolerance and summer mortality syndrome in $P$. stellatus was conducted. Cultivated organisms have the ability to overcome stress resulting from changes in their external environment to some extent, but above a certain threshold level stress can result in reduced physiological activity (Park et al., 2011). In general, the levels of hepatic markers rise dramatically under stress and are considered indicative of a key response to stress in teleosts (Jia et al., 2020). When fish are exposed to stress, corticotrophin-releasing hormone is secreted from the hypothalamus of the brain to the pituitary gland, and adrenocorticotropic hormone is secreted from the pituitary gland, resulting in increased cortisol secretion from the adrenal glands (Cockrem et al., 2019). Secreted cortisol acts as a glucocorticoid hormone, which releases glucose by allowing glycogen secretion from the liver (Vijayan et al., 2003). Therefore, blood sugar levels increase and a secondary reaction occurs that uses the released glucose as an energy source to cope with the stress (Faught and Vijayan, 2019). In the current study, the plasma cortisol levels of adult fish began to increase at $24^{\circ} \mathrm{C}$, whereas those of juvenile fish did not. Levels in both juvenile and adult fish increased significantly at $28^{\circ} \mathrm{C}$, reaching their highest values, followed by a decrease at $30^{\circ} \mathrm{C}$. Similar results under heat stress have been found in rainbow trout (Basu et al., 2001; Lewis et al., 2010), milkfish, Chanos chanos (Hanke et al., 2019), and 
olive flounder (Kim et al., 2019). Patterns of plasma glucose levels were similar pattern to those of cortisol, with adult levels starting to increase significantly at $24^{\circ} \mathrm{C}$ and peaking at $28^{\circ} \mathrm{C}$. Glucose levels were also highest at $28^{\circ} \mathrm{C}$ in juvenile fish, but were significantly lower than in adults. A recent study in Antarctic fish showed that thermal stress stimulates glycogenolysis to enable acclimatization (Guillen et al., 2019).

Lactate levels increase when blood flow decreases due to illness or shock, resulting in a decreased oxygen supply (Dando, 1969; Milligan and Girard, 1993). Plasma lactate levels were evaluated as primary and secondary responses to stress in Senegalese sole (Conde-Sieira et al., 2018); lactate levels increased significantly in response to thermal stress in olive flounder (Lu et al., 2016) and black rockfish (Song et al., 2019). In the present study, plasma lactate levels increased significantly at $28^{\circ} \mathrm{C}$ in juvenile and adult $P$. stellatus before decreasing at $30^{\circ} \mathrm{C}$. Lactate levels at 24,28 , and $30^{\circ} \mathrm{C}$ were significantly lower in juvenile fish than in adults. This implies that stress levels were higher in adult fish than in juveniles, at the same temperatures.

Defense against pathogenic infective organisms is first provided by the non-specific immune system, and includes lysozyme activity (Möck and Peters, 1990). Several studies have investigated plasma lysozyme activity to determine the effects of heat stress on the immune systems of fish (Subramanian et al., 2007; Simide et al., 2016; Dawood et al., 2020; Vakili et al., 2021), as lysozyme content is an indicator of non-specific immune function (Jung et al., 2016). Mahmoud et al. (2020) found that in Nile tilapia, Oreochromis niloticus, lysozyme activity increased significantly at $32^{\circ} \mathrm{C}$ but then decreased at $37^{\circ} \mathrm{C}$. By contrast, plasma lysozyme activity in goldfish, Carassius auratus, decreased significantly following exposure to $30^{\circ} \mathrm{C}$ (Jung et al., 2016). In the present study, lysozyme activity in both juvenile and adult $P$. stellatus increased significantly from $20^{\circ} \mathrm{C}$ to $28^{\circ} \mathrm{C}$, and was significantly higher in adult than in juvenile fish; the opposite was true at $30^{\circ} \mathrm{C}$.

In general, thermal stress can stimulate the production of endogenous ROS, thereby inducing cell injury and antioxidant responses in aquatic organisms (Heise et al., 2003; Kaur et al., 2005; Banh et al., 2016). The antioxidant enzymes SOD and CAT can remove excessive free radicals, thereby minimizing damage to cells (Shin et al., 2010). SOD activity influences the concentrations of molecular oxygen and hydrogen peroxide, the two substrates of the Haber-Weiss reaction, and is therefore likely to be critical for defense mechanisms (Bowler et al., 1992). Hydrogen peroxide is scavenged by CAT and peroxidases, which convert hydrogen peroxide to water and molecular oxygen (Bowler et al., 1992). Recent studies have reported that thermal stress can induce oxidative stress and damage to fish, including sea bream (Diplodus vulgaris) (Madeira et al., 2013), puffer fish (Takifugu obscurus) (Cheng et al., 2018), olive flounder (Lu et al., 2016), and other fish species (Mueller et al., 2012; Rossi et al., 2017; Klein et al., 2017).

Yang and Yeo (2004) reported that SOD and CAT activities significantly increase in olive flounder as the temperature rises. On the other hand, significant differences in SOD and CAT activities were not observed at high temperatures during chronic heat stress (Liu et al., 2014). In the present study, SOD activity in juvenile $P$. stellatus increased significantly at $20^{\circ} \mathrm{C}$ and then decreased at $30^{\circ} \mathrm{C}$. In adult fish, SOD activity was significantly higher at $24^{\circ} \mathrm{C}$, peaked at $28^{\circ} \mathrm{C}$, and then decreased. In adult fish, CAT activity differed significantly between $16^{\circ} \mathrm{C}$ and $28^{\circ} \mathrm{C}$, while in juvenile fish activity was significantly higher at $28^{\circ} \mathrm{C}$. Considering that the CAT activity in adult $P$. stellatus was high at $16^{\circ} \mathrm{C}$, handling during blood collection may have induced stress. Thus, SOD activity was significantly higher in adult $P$. stellatus than in juveniles, and there was no significant difference in CAT activity between adult and juvenile fish. These results indicate that thermal stress elevated cortisol levels in $P$. stellatus, thereby increasing glucose to provide additional energy for metabolism and to maintain homeostasis. In addition, levels of lactate, involved in anaerobic metabolism, increased with increasing water temperature and oxygen consumption. As ROS increased due to environmental stress, the antioxidant enzymes SOD and CAT also gradually increased, with the exception of SOD activity in juvenile $P$. stellatus. 
In animals, thermal stress increases levels of HSPs and stress hormones (Iwama et al., 1999; Sharma et al., 2013). HSP family members play a critical role in unstressed and stressed cells as molecular chaperones responsible for the repair of damaged proteins and for the folding of new proteins (Jia et al., 2020). HSP expression increases following cellular stress resulting from exposure to high temperatures and oxidative damage, and has been detected in every organism evaluated (Feder and Hofmann, 1999; Kregel, 2002). Environmental stressors can affect expression of HSP70 and HSP90, which have been used as biomarkers to assess organisms' response to environmental stress (Iwama et al., 2004; Akbarzadeh et al., 2018). In the present study, expression of HSP70 in juvenile $P$. stellatus was significantly higher at $28^{\circ} \mathrm{C}$, and then decreased at $30^{\circ} \mathrm{C}$. In adult fish, HSP70 expression was significantly higher at both 28 and $30^{\circ} \mathrm{C}$. In addition, expression differed significantly between juvenile and adult $P$. stellatus from 24 to $30^{\circ} \mathrm{C}$. In both juvenile and adult fish, HSP90 expression was significantly higher only at $28^{\circ} \mathrm{C}$, with no significant difference between the two age groups.

Several studies have shown that the response to high temperature varies depending on the age or developmental stage of the fish. Fowler et al. (2009) compared thermal resistance between juvenile and adult rainbow trout and showed that an enhanced heat shock response may contribute to greater thermal resistance in juvenile fish. Meakin et al. (2014) reported that juveniles can cope with high temperatures better than adults, which offers a partial explanation for the movement patterns of fish in nature, in which younger fish inhabit near-shore waters and then migrate to deep water as they mature. The reason for the difference in thermal tolerance with age is deterioration of the HSP system (Wheeler et al., 1995; Verbeke et al., 2001; Tower, 2009), which can react to thermal stress; once sexual maturity is reached, the HSP system may be evolutionarily dispensable, as increased fitness may be attained by spending less energy on protection and more on reproduction (Sørensen and Loeschcke, 2002). In the present study, the physiological response changed, and expression of HSP genes decreased as fish aged, indicating that juvenile fish were more resistant to high temperatures than were adult fish.

Overall, this study demonstrated that the levels of several parameters, including plasma cortisol, glucose, lactate, SOD, CAT, and HSP70/90 expression, increased with thermal stress. In addition, by comparing the physiological response to high temperatures of juvenile and adult $P$. stellatus, we confirmed stronger thermal tolerance in juvenile than in adult fish. These results indicate that adult $P$. stellatus initiate a positive physiological response to cope with thermal-stress-induced damage at $28^{\circ} \mathrm{C}$, while low mortality rates were observed in juveniles. As HSP70 expression is more active in juvenile, it is judged that the requirements of plasma parameters related stress were higher due to the slow HSP70 activity of adult P. stellatus. In the case of juvenile, HSP70 activity was high, and heat response could appear earlier, so it is thought that the levels of plasma parameters could remain relatively stable. In addition, these data strengthen our understanding of the age-related physiological mechanism of $P$. stellatus during thermal stress and may help guide the management of $P$. stellatus in fish farms. Finally, to further elucidate the differences in heat tolerance between juvenile and adult $P$. stellatus, additional studies are needed, not only to investigate hematological parameters and HSP genes but also the expression of other genes.

\section{Acknowledgements}

This study was supported by the Korea Institute of Marine Science \& Technology Promotion, South Korea (Assignment No. 20180373).

\section{Conflict of interests}

The authors have declared that no competing interests exist. 


\section{Author contributions}

HB Lee designed the experiments. HB Lee and IY Lee performed the experiments. JH Yoon and JY Park assisted with the experiments and analyzed the data. HB Lee interpreted the data and drafted the manuscript. HK Lim revised the manuscript and supervised the study design and data analysis. All authors contributed intellectual content to the revisions and approved the final version for publication.

\section{Data availability statement}

The data supporting the findings of this study are available upon request from the corresponding author.

\section{References}

Alfonso, S., Gesto, M., Sadoul, B., 2021. Temperature increase and its effects on fish stress physiology in the context of global warming. Journal of Fish Biology, 98(6), 1496-1508. https://doi.org/10.1111/jfb.14599

Akbarzadeh, A., Günther, O. P., Houde, A. L., Li, S., Ming, T. J., Jeffries, K. M., Miller, K. M., 2018. Developing specific molecular biomarkers for thermal stress in salmonids. BMC genomics, 19(1), 1-28. https://doi.org/10.1186/s12864-018-5108-9

Banh, S., Wiens, L., Sotiri, E., Treberg, J. R., 2016. Mitochondrial reactive oxygen species production by fish muscle mitochondria: potential role in acute heat-induced oxidative stress. Comparative Biochemistry and Physiology Part B: Biochemistry and Molecular Biology, 191, 99-107. https://doi.org/10.1016/j.cbpb.2015.10.001 Barton, B. A., Iwama, G. K., 1991. Physiological changes in fish from stress in aquaculture with emphasis on the response and effects of corticosteroids. Annual Review of fish diseases, 1, 3-26. https://doi.org/10.1016/09598030(91)90019-G

Barton, B. A., 2000. Salmonid fishes differ in their cortisol and glucose responses to handling and transport stress. North American Journal of Aquaculture, 62(1), 12-18. https://doi.org/10.1577/15488454(2000)062<0012:SFDITC>2.0.CO;2

Basu, N., Nakano, T., Grau, E. G., Iwama, G. K., 2001. The effects of cortisol on heat shock protein 70 levels in two fish species. General and comparative endocrinology, 124(1), 97-105. https://doi.org/10.1006/gcen.2001.7688

Basu, N., Todgham, A. E., Ackerman, P. A., Bibeau, M. R., Nakano, K., Schulte, P. M., Iwama, G. K., 2002. Heat shock protein genes and their functional significance in fish. Gene, 295(2), 173-183. https://doi.org/10.1016/S0378-1119(02)00687-X

Begg, K., Pankhurst, N. W., 2004. Endocrine and metabolic responses to stress in a laboratory population of the tropical damselfish Acanthochromis polyacanthus. Journal of Fish Biology, 64(1), 133-145. https://doi.org/10.1111/j.1095-8649.2004.00290.x

Bowler, C., Montagu, M. V., Inze, D., 1992. Superoxide dismutase and stress tolerance. Annual review of plant biology, 43(1), 83-116.

Byun, S. G., Jeong, M. H., Lee, J. H., Lee, B. I., Ku, H. D., Park, S. U., Chang, Y. J., 2008. Diel rhythm of oxygen consumption of the starry flounder Platichthys stellatus by water temperature. Korean Journal of Fisheries and Aquatic Sciences, 41(2), 113-118. https://doi.org/10.5657/kfas.2008.41.2.113

Cheng, A. C., Cheng, S. A., Chen, Y. Y., Chen, J. C., 2009. Effects of temperature change on the innate cellular and humoral immune responses of orange-spotted grouper Epinephelus coioides and its susceptibility to Vibrio alginolyticus. Fish \& shellfish immunology, 26(5), 768-772. https://doi.org/10.1016/i.fsi.2009.03.011

Cheng, C. H., Guo, Z. X., Luo, S. W., Wang, A. L., 2018. Effects of high temperature on biochemical parameters, oxidative stress, DNA damage and apoptosis of pufferfish (Takifugu obscurus). Ecotoxicology and environmental safety, 150, 190-198. https://doi.org/10.1016/j.ecoenv.2017.12.045

Cockrem, J. F., Bahry, M. A., Chowdhury, V. S., 2019. Cortisol responses of goldfish (Carassius auratus) to air exposure, chasing, and increased water temperature. General and comparative endocrinology, 270, 18-25. https://doi.org/10.1016/j.ygcen.2018.09.017

Conde-Sieira, M., Gesto, M., Batista, S., Linares, F., Villanueva, J. L., Míguez, J. M., Valente, L. M., 2018. Influence of vegetable diets on physiological and immune responses to thermal stress in Senegalese sole (Solea senegalensis). PloS one, 13(3), e0194353.https://doi.org/10.1371/journal.pone.0194353

Csermely, P., Schnaider, T., So, C., Prohászka, Z., Nardai, G., 1998. The 90-kDa molecular chaperone family: structure, function, and clinical applications. A comprehensive review. Pharmacology \& therapeutics, 79(2), 129168. https://doi.org/10.1016/S0163-7258(98)00013-8

Dando, P. R., 1969. Lactate metabolism in fish. Journal of the Marine Biological Association of the United Kingdom, 49(1), 209-223. https://doi.org/10.1017/S002531540004652X

Dawood, M. A., Metwally, A. E. S., El-Sharawy, M. E., Ghozlan, A. M., Abdel-Latif, H. M., Van Doan, H., Ali, M. A., 2020. The influences of ferulic acid on the growth performance, haemato-immunological responses, and 
immune-related genes of Nile tilapia (Oreochromis niloticus) exposed to heat stress. Aquaculture, 525, 735320. https://doi.org/10.1016/j.aquaculture.2020.735320

Di Marco, P., Priori, A., Finoia, M. G., Massari, A., Mandich, A., Marino, G., 2008. Physiological responses of European sea bass Dicentrarchus labrax to different stocking densities and acute stress challenge. Aquaculture, 275(1-4), 319-328. https://doi.org/10.1016/j.aquaculture.2007.12.012

Drost, H. E., Lo, M., Carmack, E. C., Farrell, A. P., 2016. Acclimation potential of Arctic cod (Boreogadus saida) from the rapidly warming Arctic Ocean. Journal of Experimental biology, 219(19), 3114-3125. https://doi.org/10.1242/jeb.140194

Fast, M. D., Hosoya, S., Johnson, S. C., Afonso, L. O., 2008. Cortisol response and immune-related effects of Atlantic salmon (Salmo salar Linnaeus) subjected to short-and long-term stress. Fish \& shellfish immunology, 24(2), 194-204. https://doi.org/10.1016/j.fsi.2007.10.009

Faught, E., Vijayan, M. M., 2019. Loss of the glucocorticoid receptor in zebrafish improves muscle glucose availability and increases growth. American Journal of Physiology-Endocrinology and Metabolism, 316(6), 10931104. https://doi.org/10.1152/ajpendo.00045.2019

Feder, M. E., Hofmann, G. E., 1999. Heat-shock proteins, molecular chaperones, and the stress response: evolutionary and ecological physiology. Annual review of physiology, 61(1), 243-282.

Fevolden, S. E., Refstie, T., Røed, K. H., 1991. Selection for high and low cortisol stress response in Atlantic salmon (Salmo salar) and rainbow trout (Oncorhynchus mykiss). Aquaculture, 95(1-2), 53-65. https://doi.org/10.1016/0044-8486(91)90072-F

Fletcher, T. C., White, A., 1976. The lysozyme of the plaice Pleuronectes platessa L. Comparative Biochemistry and Physiology Part B: Comparative Biochemistry, 55(2), 207-210. https://doi.org/10.1016/0305-0491(76)90231$\underline{5}$

Fowler, S. L., Hamilton, D., Currie, S., 2009. A comparison of the heat shock response in juvenile and adult rainbow trout (Oncorhynchus mykiss) -implications for increased thermal sensitivity with age. Canadian Journal of Fisheries and Aquatic Sciences, 66(1), 91-100. https://doi.org/10.1139/F08-192

Fu, D., Chen, J., Zhang, Y., Yu, Z., 2011. Cloning and expression of a heat shock protein (HSP) 90 gene in the haemocytes of Crassostrea hongkongensis under osmotic stress and bacterial challenge. Fish \& shellfish immunology, 31(1), 118-125. https://doi.org/10.1016/j.fsi.2011.04.011

Gesto, M., Álvarez-Otero, R., Conde-Sieira, M., Otero-Rodiño, C., Usandizaga, S., Soengas, J. L., LópezPatiño, M. A., 2016. A simple melatonin treatment protocol attenuates the response to acute stress in the sole Solea senegalensis. Aquaculture, 452, 272-282. https://doi.org/10.1016/j.aquaculture.2015.11.006

Guillen, A. C., Borges, M. E., Herrerias, T., Kandalski, P. K., de Arruda Marins, E., Viana, D., Donatti, L., 2019. Effect of gradual temperature increase on the carbohydrate energy metabolism responses of the Antarctic fish Notothenia rossii. Marine environmental research, 150, 104779. https://doi.org/10.1016/j.marenvres.2019.104779

Hamdan, R., Kari, F., Othman, A., 2015. Biophysical Vulnerability Impact Assessment of Climate Change on Aquaculture Sector Development in Sarawak, Malaysia. DLSU Business \& Economics Review, 24(2). 32-44.

Hanke, I., Ampe, B., Kunzmann, A., Gärdes, A., Aerts, J., 2019. Thermal stress response of juvenile milkfish (Chanos chanos) quantified by ontogenetic and regenerated scale cortisol. Aquaculture, 500, 24-30. https://doi.org/10.1016/j.aquaculture.2018.09.016

Heise, K., Puntarulo, S., Pörtner, H. O., Abele, D., 2003. Production of reactive oxygen species by isolated mitochondria of the Antarctic bivalve Laternula elliptica (King and Broderip) under heat stress. Comparative Biochemistry and Physiology Part C: Toxicology \& Pharmacology, 134(1), 79-90. https://doi.org/10.1016/S15320456(02)00212-0

Hemre, G. I., Mommsen, T. P., Krogdahl, A., 2002. Carbohydrates in fish nutrition: effects on growth, glucose metabolism and hepatic enzymes. Aquaculture nutrition, 8(3), 175-194. https://doi.org/10.1046/j.13652095.2002.00200.x

Iwama, G. K., Thomas, P. T., Forsyth, R. B., Vijayan, M. M., 1998. Heat shock protein expression in fish. Reviews in Fish Biology and Fisheries, 8(1), 35-56. https://doi.org/10.1023/A:1008812500650

Iwama, G. K., Vijayan, M. M., Forsyth, R. B., Ackerman, P. A., 1999. Heat shock proteins and physiological stress in fish. American Zoologist, 39(6), 901-909. https://doi.org/10.1093/icb/39.6.901

Iwama, G. K., Afonso, L. O., Todgham, A., Ackerman, P., Nakano, K., 2004. Are hsps suitable for indicating stressed states in fish?. Journal of experimental biology, 207(1), 15-19. https://doi.org/10.1242/jeb.00707

Jacob, P., Hirt, H., Bendahmane, A., 2017. The heat-shock protein/chaperone network and multiple stress resistance. Plant biotechnology journal, 15(4), 405-414. https://doi.org/10.1111/pbi.12659

Jia, Y., Chen, X., Wang, Z., Meng, Z., Huang, B., Guan, C., 2020. Physiological response of juvenile turbot (Scophthalmus maximus. L) during hyperthermal stress. Aquaculture, 529, 735645. https://doi.org/10.1016/j.aquaculture.2020.735645

Jiang, D., Wu, Y., Huang, D., Ren, X., Wang, Y., 2017. Effect of blood glucose level on acute stress response of grass carp Ctenopharyngodon idella. Fish physiology and biochemistry, 43(5), 1433-1442. https://doi.org/10.1007/s10695-017-0383-y

Jung, S. J., Choi, Y. J., Kim, N. N., Choi, J. Y., Kim, B. S., Choi, C. Y., 2016. Effects of melatonin injection or green-wavelength LED light on the antioxidant system in goldfish (Carassius auratus) during thermal stress. Fish \& shellfish immunology, 52, 157-166. https://doi.org/10.1016/i.fsi.2016.03.002 
Kaur, M., Atif, F., Ali, M., Rehman, H., Raisuddin, S., 2005. Heat stress-induced alterations of antioxidants in the freshwater fish Channa punctata Bloch. Journal of fish biology, 67(6), 1653-1665. https://doi.org/10.1111/j.1095-8649.2005.00872.x

Kayhan, F. E., Duman, B. S., 2010. Heat shock protein genes in fish. Turkish Journal of Fisheries and Aquatic Sciences, 10(2). 287-293. https://doi.org/10.4194/trifas.2010.0218

Kelly, N. I., Wilson, C. C., Currie, S., Burness, G., 2018. Acclimation capacity of the cardiac HSP70 and HSP90 response to thermal stress in lake trout (Salvelinus namaycush), a stenothermal ice-age relict. Comparative Biochemistry and Physiology Part B: Biochemistry and Molecular Biology, 224, 53-60. https://doi.org/10.1016/j.cbpb.2017.12.002

Kilgour, D. M., McCauley, R. W., 1986. Reconciling the two methods of measuring upper lethal temperatures in fishes. Environmental Biology of Fishes, 17(4), 281-290. https://doi.org/10.1007/BF00001494

Kim, P. K., 2012. Growth performance and digestive characteristics of starry flounder Platichthys stellatus on the moist and extruded pellets. Korean Journal of Fisheries and Aquatic Sciences, 45(6), 679-685. https://doi.org/10.5657/KFAS.2012.0679

Kim, J. H., Kim, S. K., Hur, Y. B., 2019. Temperature-mediated changes in stress responses, acetylcholinesterase, and immune responses of juvenile olive flounder Paralichthys olivaceus in a bio-floc environment. Aquaculture, 506, 453-458. https://doi.org/10.1016/j.aquaculture.2019.03.045

Klein, R. D., Borges, V. D., Rosa, C. E., Colares, E. P., Robaldo, R. B., Martinez, P. E., Bianchini, A., 2017. Effects of increasing temperature on antioxidant defense system and oxidative stress parameters in the Antarctic fish Notothenia coriiceps and Notothenia rossii. Journal of thermal biology, 68, 110-118. https://doi.org/10.1016/j.jtherbio.2017.02.016

Kregel, K. C., 2002. Invited review: heat shock proteins: modifying factors in physiological stress responses and acquired thermotolerance. Journal of applied physiology, 92(5), 2177-2186. https://doi.org/10.1152/japplphysiol.01267.2001

Lee, S., Ji, K., Choi, K., 2014. Effects of water temperature on perchlorate toxicity to the thyroid and reproductive system of Oryzias latipes. Ecotoxicology and environmental safety, 108, 311-317. https://doi.org/10.1016/j.ecoenv.2014.07.016

Lewis, J. M., Hori, T. S., Rise, M. L., Walsh, P. J., Currie, S., 2010. Transcriptome responses to heat stress in the nucleated red blood cells of the rainbow trout (Oncorhynchus mykiss). Physiological genomics, 42(3), 361373.

Liu, B., Xie, J., Ge, X., Xu, P., Wang, A., He, Y., Chen, R., 2010. Effects of anthraquinone extract from Rheum officinale Bail on the growth performance and physiological responses of Macrobrachium rosenbergii under high temperature stress. Fish \& shellfish immunology, 29(1), 49-57. https://doi.org/10.1016/j.fsi.2010.02.018

Liu, Y., Ma, D., Zhao, C., Wang, W., Zhang, X., Liu, X., Li, J., 2014. Histological and enzymatic responses of Japanese flounder (Paralichthys olivaceus) and its hybrids $\left(P\right.$. olivaceus $\odot \times P$. dentatus $\left.{ }^{\lambda}\right)$ to chronic heat stress. Fish physiology and biochemistry, 40(4), 1031-1041. https://doi.org/10.1007/s10695-013-9903-6

López -Patiño, M. A., Conde-Sieira, M., Gesto, M., Librán-Pérez, M., Soengas, J. L., Míguez, J. M., 2013. Melatonin partially minimizes the adverse stress effects in Senegalese sole (Solea senegalensis). Aquaculture, 388, 165-172. https://doi.org/10.1016/j.aquaculture.2013.01.023

Lowe, C. J., Davison, W., 2005. Plasma osmolarity, glucose concentration and erythrocyte responses of two Antarctic nototheniid fishes to acute and chronic thermal change. Journal of Fish Biology, 67(3), 752-766. https://doi.org/10.1111/j.0022-1112.2005.00775.x

Lu, Y., Wu, Z., Song, Z., Xiao, P., Liu, Y., Zhang, P., You, F., 2016. Insight into the heat resistance of fish via blood: Effects of heat stress on metabolism, oxidative stress, and antioxidant response of olive flounder Paralichthys olivaceus and turbot Scophthalmus maximus. Fish \& shellfish immunology, 58, 125-135. https://doi.org/10.1016/j.fsi.2016.09.008

Madeira, D., Narciso, L., Cabral, H. N., Vinagre, C., Diniz, M. S., 2013. Influence of temperature in thermal and oxidative stress responses in estuarine fish. Comparative Biochemistry and Physiology Part A: Molecular \& Integrative Physiology, 166(2), 237-243. https://doi.org/10.1016/j.cbpa.2013.06.008

Mahmoud, S., Sabry, A., Abdelaziz, A., Shukry, M., 2020. Deleterious impacts of heat stress on steroidogenesis markers, immunity status and ovarian tissue of Nile tilapia (Oreochromis niloticus). Journal of Thermal Biology, 91, 102578. https://doi.org/10.1016/j.jtherbio.2020.102578

Meakin, C. A., Qin, J. G., Pogson, L. D., Abbott, C. A., 2014. Thermal tolerance in juvenile King George whiting (Sillaginodes punctata) reduces as fish age and this reduction coincides with migration to deeper colder water. Comparative Biochemistry and Physiology Part A: Molecular \& Integrative Physiology, 172, 46-51. https://doi.org/10.1016/j.cbpa.2014.02.016

Min, B. H., Park, M. S., Myeong, J. L., 2015. Stress responses of starry flounder, Platichthys stellatus (Pallas) following water temperature rise. Journal of environmental biology, 36(5), 1057-1062.

Milligan, C. L., Girard, S. S., 1993. Lactate metabolism in rainbow trout. Journal of Experimental Biology, 180(1), 175-193. https://doi.org/10.1242/jeb.180.1.175

Mirghaed, A. T., Ghelichpour, M., Hoseini, S. M., Amini, K., 2017. Hemolysis interference in measuring fish plasma biochemical indicators. Fish Physiology and Biochemistry, 43(4), 1143-1151. https://doi.org/10.1007/s10695-017-0359-y 
Möck, A., Peters, G., 1990. Lysozyme activity in rainbow trout, Oncorhynchus mykiss (Walbaum), stressed by handling, transport, and water pollution. Journal of Fish Biology, 37(6), 873-885. https://doi.org/10.1111/j.10958649.1990.tb03591.x

Moyano, M., Candebat, C., Ruhbaum, Y., Alvarez-Fernandez, S., Claireaux, G., Zambonino-Infante, J. L., Peck, M. A., 2017. Effects of warming rate, acclimation temperature and ontogeny on the critical thermal maximum of temperate marine fish larvae. PLoS One, 12(7), e0179928. https://doi.org/10.1371/journal.pone.0179928 Mueller, I. A., Devor, D. P., Grim, J. M., Beers, J. M., Crockett, E. L., O'Brien, K. M., 2012. Exposure to critical thermal maxima increases oxidative stress in hearts of white-but not red-blooded Antarctic notothenioid fishes. Journal of Experimental Biology, 215(20), 3655-3664. https://doi.org/10.1242/jeb.071811

Muona, M., Soivio, A., 1992. Changes in plasma lysozyme and blood leucocyte levels of hatchery-reared Atlantic salmon (Salmo salar L.) and sea trout (Salmo trutta L.) during parr-smolt transformation. Aquaculture, 106(1), 7587. https://doi.org/10.1016/0044-8486(92)90251-F

Ndong, D., Chen, Y. Y., Lin, Y. H., Vaseeharan, B., Chen, J. C., 2007. The immune response of tilapia Oreochromis mossambicus and its susceptibility to Streptococcus iniae under stress in low and high temperatures. Fish \& Shellfish Immunology, 22(6), 686-694. https://doi.org/10.1016/j.fsi.2006.08.015

Oh, S. Y., Jang, Y. S., Noh, C. H., Choi, H. J., Myoung, J. G., Kim, C. K., 2009. Effect of water temperature and body weight on oxygen consumption rate of starry flounder Platichthys stellatus. Korean Journal of Ichthyology, 21(1), 7-14.

Paaijmans, K. P., Heinig, R. L., Seliga, R. A., Blanford, J. I., Blanford, S., Murdock, C. C., Thomas, M. B., 2013. Temperature variation makes ectotherms more sensitive to climate change. Global change biology, 19(8), 2373-2380. https://doi.org/10.1111/gcb.12240

Paital, B., Chainy, G. B. N., 2016. Redox metabolism in fishes under thermal stress warrants more attention. Journal of Fisheriessciences. com, 10(1), 22-26. https://doi.org/10(1): 022-026 (2016)

Paital, B., Panda, S. K., Hati, A. K., Mohanty, B., Mohapatra, M. K., Kanungo, S., Chainy, G. B. N., 2016. Longevity of animals under reactive oxygen species stress and disease susceptibility due to global warming. World journal of biological chemistry, 7(1), 110-127. https://doi.org/10.4331/wjbc.v7.i1.110

Park, C. J., Min, B. H., Kim, K. S., Lee, J. W., Lee, J. H., Noh, J. K., Myeong, J. I., 2011. Physiological responses on low water-temperature stress of Pacific abalone, Haliotis discus hannai. The Korean Journal of Malacology, 27(4), 317-322. https://doi.org/10.9710/kjm.2011.27.4.317

Payne, N. L., Smith, J. A., van der Meulen, D. E., Taylor, M. D., Watanabe, Y. Y., Takahashi, A., Suthers, I. M., 2016. Temperature dependence of fish performance in the wild: links with species biogeography and physiological thermal tolerance. Functional Ecology, 30(6), 903-912. https://doi.org/10.1111/1365-2435.12618

Pérez-Casanova, J. C., Afonso, L. O. B., Johnson, S. C., Currie, S., Gamperl, A. K., 2008. The stress and metabolic responses of juvenile Atlantic cod Gadus morhua L. to an acute thermal challenge. Journal of Fish Biology, 72(4), 899-916. https://doi.org/10.1111/j.1095-8649.2007.01763.x

Pottinger, T. G., Moran, T. A., Morgan, J. A. W., 1994. Primary and secondary indices of stress in the progeny of rainbow trout (Oncorhynchus mykiss) selected for high and low responsiveness to stress. Journal of Fish Biology, 44(1), 149-163. https://doi.org/10.1111/j.1095-8649.1994.tb01591.x

Pottinger, T. G., Carrick, T. R., 1999. A comparison of plasma glucose and plasma cortisol s selection markers for high and low stress-responsiveness in female rainbow trout. Aquaculture, 175(3-4), 351-363. https://doi.org/10.1016/S0044-8486(99)00107-6

Radoslav, D., Aleksandar, I., Rajko, G., Goran, T., Danijela, C.., Svjetlana, L., 2013. Effect of thermal stress of short duration on the red blood cell parameters of Barbus balcanicus Kotlik, Tsigenopulos, Rab, Berrebi, 2002. African Journal of Biotechnology, 12(18). https://doi.org/10.5897/AJB12.1800

Ramsay, J. M., Feist, G. W., Varga, Z. M., Westerfield, M., Kent, M. L., Schreck, C. B., 2009. Whole-body cortisol response of zebrafish to acute net handling stress. Aquaculture, 297(1-4), 157-162. https://doi.org/10.1016/j.aquaculture.2009.08.035

Rossi, A., Bacchetta, C., Cazenave, J., 2017. Effect of thermal stress on metabolic and oxidative stress biomarkers of Hoplosternum littorale (Teleostei, Callichthyidae). Ecological Indicators, 79, 361-370. https://doi.org/10.1016/j.ecolind.2017.04.042

Ruane, N. M., Huisman, E. A., Komen, J., 2001. Plasma cortisol and metabolite level profiles in two isogenic strains of common carp during confinement. Journal of fish biology, 59(1), 1-12. https://doi.org/10.1111/j.10958649.2001.tb02334.x

Sathiyaa, R., Campbell, T., Vijayan, M. M., 2001. Cortisol modulates HSP90 mRNA expression in primary cultures of trout hepatocytes. Comparative Biochemistry and Physiology Part B: Biochemistry and Molecular Biology, 129(2-3), 679-685. https://doi.org/10.1016/S1096-4959(01)00373-6

Sharma, S., Ramesh, K., Hyder, I., Uniyal, S., Yadav, V. P., Panda, R. P., Sarkar, M., 2013. Effect of melatonin administration on thyroid hormones, cortisol and expression profile of heat shock proteins in goats (Capra hircus) exposed to heat stress. Small Ruminant Research, 112(1-3), 216-223. https://doi.org/10.1016/i.smallrumres.2012.12.008

Shin, H. S., An, K. W., Kim, N. N., Choi, C. Y., 2010. Antioxidant defenses and physiological changes in olive flounder (Paralichthys olivaceus) in response to oxidative stress induced by elevated water temperature. Korean Journal of Ichthyology, 22(1), 1-8.

Simide, R., Richard, S., Prévot-D'Alvise, N., Miard, T., Gaillard, S., 2016. Assessment of the accuracy of physiological blood indicators for the evaluation of stress, health status and welfare in Siberian sturgeon 
(Acipenser baerii) subject to chronic heat stress and dietary supplementation. International Aquatic Research, 8(2), 121-135. https://doi.org/10.1007/s40071-016-0128-Z

Song, M., Zhao, J., Wen, H. S., Li, Y., Li, J. F., Li, L. M., Tao, Y. X., 2019. The impact of acute thermal stress on the metabolome of the black rockfish (Sebastes schlegelii). PloS one, 14(5), e0217133. https://doi.org/10.1371/journal.pone.0217133

Sørensen, J. G., Loeschcke, V., 2002. Decreased heat-shock resistance and down-regulation of Hsp70 expression with increasing age in adult Drosophila melanogaster. Functional Ecology, 16(3), 379-384. https://doi.org/10.1046/j.1365-2435.2002.00639.x

Stirling, H. P., 1982. The upper temperature tolerance of prosobranch gastropods of rocky shores at Hong Kong and Dar ES Salaam, Tanzania. Journal of Experimental Marine Biology and Ecology, 63(2), 133-144. https://doi.org/10.1016/0022-0981(82)90027-2

Subramanian, S., MacKinnon, S. L., Ross, N. W., 2007. A comparative study on innate immune parameters in the epidermal mucus of various fish species. Comparative Biochemistry and Physiology Part B: Biochemistry and Molecular Biology, 148(3), 256-263. https://doi.org/10.1016/j.cbpb.2007.06.003

Tedeschi, J. N., Kennington, W. J., Berry, O., Whiting, S., Meekan, M., Mitchell, N. J., 2015. Increased expression of Hsp70 and Hsp90 mRNA as biomarkers of thermal stress in loggerhead turtle embryos (Caretta caretta). Journal of thermal biology, 47, 42-50. https://doi.org/10.1016/i.jtherbio.2014.11.006

Tower, J., 2009. Hsps and aging. Trends in Endocrinology \& Metabolism, 20(5), $216-222$. https://doi.org/10.1016/i.tem.2008.12.005

Troia, M. J., Whitney, J. E., Gido, K. B., 2015. Thermal performance of larval longfin dace (Agosia chrysogaster), with implications for climate change. Environmental biology of fishes, 98(1), 395-404. https://doi.org/10.1007/s10641-014-0270-7

Turko, A. J., Nolan, C. B., Balshine, S., Scott, G. R., Pitcher, T. E., 2020. Thermal tolerance depends on season, age and body condition in imperilled redside dace Clinostomus elongatus. Conservation Physiology, 8(1), 1-15. https://doi.org/10.1093/conphys/coaa062

Vakili, F., Roosta, Z., Hoseinifar, S. H., Akbarzadeh, A., 2021. Effects of thermal stress and hypoxia on skin mucus immune and stress responses in blue gourami (Trichogaster trichopterus) cultured in intensive recirculation aquaculture system and semi-intensive systems. Aquaculture Research. 1-10. https://doi.org/10.1111/are.15529

Verbeke, P., Fonager, J., Clark, B. F., Rattan, S. I., 2001. Heat shock response and ageing: mechanisms and applications. Cell biology international, 25(9), 845-857. https://doi.org/10.1006/cbir.2001.0789

Vijayan, M. M., Raptis, S., Sathiyaa, R., 2003. Cortisol treatment affects glucocorticoid receptor and glucocorticoid-responsive genes in the liver of rainbow trout. General and comparative endocrinology, 132(2), 256-263. https://doi.org/10.1016/S0016-6480(03)00092-3

Voellmy, R., Boellmann, F., 2007. Chaperone regulation of the heat shock protein response. Molecular Aspects of the Stress Response: Chaperones, Membranes and Networks, 89-99. https://doi.org/10.1007/978-0-38739975-1_9

Wei, T., Gao, Y., Wang, R., Xu, T., 2013. A heat shock protein $90 \beta$ isoform involved in immune response to bacteria challenge and heat shock from Miichthys miiuy. Fish \& shellfish immunology, 35(2), 429-437. https://doi.org/10.1016/j.fsi.2013.04.045

Wheeler, J. C., King, V., Tower, J., 1999. Sequence requirements for upregulated expression of Drosophila hsp70 transgenes during aging. Neurobiology of aging, 20(5), 545-553. https://doi.org/10.1016/S01974580(99)00088-3

Wu, H., Ohnuki, H., Ota, S., Murata, M., Yoshiura, Y., Endo, H., 2017. New approach for monitoring fish stress: A novel enzyme-functionalized label-free immunosensor system for detecting cortisol levels in fish. Biosensors and Bioelectronics, 93, 57-64. https://doi.org/10.1016/i.bios.2016.10.001

Xu, D., Sun, L., Liu, S., Zhang, L., Yang, H., 2014. Polymorphisms of heat shock protein 90 (Hsp90) in the sea cucumber Apostichopus japonicus and their association with heat-resistance. Fish \& shellfish immunology, 41(2), 428-436. https://doi.org/10.1016/j.fsi.2014.09.025

Yamashita, M., Yabu, T., Ojima, N., 2010. Stress protein HSP70 in fish. Aqua-BioScience Monographs, 3(4), 111-141. https://doi.org/10.5047/absm.2010.00304.0111

Yang, J. H., Yeo, I. K., 2004. Physiological studies on acute water-temperature stress of olive flounder (Paralichthys olivaceus). Korean J Ichthyol, 16, 19-26.

Yu, H., Deng, W., Zhang, D., Gao, Y., Yang, Z., Shi, X., Ji, H., 2017. Antioxidant defenses of Onychostoma macrolepis in response to thermal stress: insight from mRNA expression and activity of superoxide dismutase and catalase. Fish \& shellfish immunology, 66, 50-61. https://doi.org/10.1016/i.fsi.2017.04.027 